\title{
ФТОРИДЫ: ИХ ЗНАЧЕНИЕ ДЛЯ ЗДОРОВЬЯ ЧЕЛОВЕКА В СОВРЕМЕННЫХ УСЛОВИЯХ И ПЕРСПЕКТИВЫ ИСПОЛЬЗОВАНИЯ
}

\author{
○ Иорданишвили А.К. \\ Северо-Западный государственный медицинский университет им. И.И. Мечникова \\ (СЗГМУ им. И.И. Мечникова) \\ Россия, 191015, г. Санкт-Петербург, ул. Кирочная, д. 41 \\ Военно-медицинская академия им. С.М. Кирова (ВМедА им. С.М. Кирова) \\ Россия, 194044, г. Санкт-Петербург, ул. Академика Лебедева, д. 6 \\ Международная академия наук экологии, безопасности человека и природы (МАНЭБ) \\ Россия, 199106, г. Санкт-Петербург, Большой пр., д. 74
}

\begin{abstract}
Освещаются актуальные в современных условиях вопросы, связанные с потреблением населением России фторидов, включая индивидуальные средства ухода за полостью рта. Отмечается, что фториды имеют безусловное физиологическое значение для организма человека, его здоровья, в том числе стоматологического. Эффективность фтористых препаратов и их влияние на снижение кариеса зубов широко документирована в зарубежной и отечественной литературе и является неоспоримым фактом. Несмотря на то что нет общепринятого согласия на механизм действия фтора, нет сомнений в отношении его противокариозного действия. Наиболее интенсивное включение фторидов в состав твердых тканей зубов происходит во время их формирования и минерализации. По окончании роста и минерализации зубов эмаль и дентин зубов становятся менее проницаемыми для ионов фтора. Оптимальной ежедневный прием фторидов должен колебаться между 0,05 и 0,07 мг/кг массы тела. Общий прием фторидов не должен превышать 0,1 мг/кг массы в день, чтобы избежать появления флюороза зубов и костей. Даны рекомендации по использованию фторидсодержащих средств ухода за полостью рта. Отмечено, что проблема сохранения соматического и стоматологического здоровья у населения России, в том числе профилактики кариеса зуба, должна решаться в контексте климато-географических, экологических, медицинских и социальных аспектов, в решении которой фторидам должно отводиться не последнее место.

Ключевые слова: фториды, здоровье человека, гигиеническое значение фтора, безопасность применения фтора, фторид олова, монофторфосфат натрия, фторид натрия, фторид алюминия.
\end{abstract}

Иорданишвили Андрей Константинович - д.м.н., профессор кафедры ортопедической стоматологии, СЗГМУ им. И.И. Мечникова, г. Санкт-Петербург; профессор кафедры челюстно-лицевой хирургии и хирургической стоматологии, ВМедА им. С.М. Кирова, г. Санкт-Петербург; главный Ученый секретарь, МАНЭБ, г. Санкт-Петербург. E-mail: $\underline{\text { mdgrey@bk.ru }}$

В настоящее время в отечественной и зарубежной литературе имеются сведения о распространенности фторидов в природе, содержании их и обмене в организме, роли фторидов как фактора заболеваемости флюорозом и снижения заболеваемости кариесом зубов $[1,2,5]$. Проблема влияния фторидов на организм и здоровье человека освещалась с середины до 90-х годов прошлого века в широком гигиеническом плане, применительно к задачам гигиены труда и гигиены питания, а также санитарной охраны атмосферного воздуха и источников водоснабжения $[3,4]$. В нашей стране были проведены обширные исследования природных вод на фториды и очаги эндемического флюороза, а также многолетние санитарно-токсикологические исследования влияния фторидов на организм человека, что обобщено в конце прошлого века и по-началу находило практическое применение [3]. В настоящее время сохраняется актуальное отношение к фторидам применительно к задачам гигиены труда, гигиены питания, а также санитарной охраны окружающей среды, в том числе производственной, в отношении из- быточного содержания фторидов, но снизилось внимание к фторидам в широком гигиеническом плане, особенно в связи с основной стоматологической патологией - кариесом зубов. Это происходит, не смотря на то, что 100 млн. человек в России сегодня пьют воду с недостаточным содержанием фтора и йода [22]. То есть, можно предположить, что каждые два из трех жителей нашей страны находятся в условиях недостаточного поступления фторидов. Во многих регионах России из-за недостаточного содержания в воде необходимых для здоровья микроэлементов (фтора) поражение кариесом зубов у детей достигает $90-100 \%$ [15]. Также следует отметить, что в современных условиях из более 2000 различных видов зубных паст, присутствующих на современном рынке в России, более $20 \%$ из них не содержат фтор [18]. Применение таких паст у детей, подростков и взрослых, при условии сниженного содержания фторидов или их полного отсутствия в питьевой воде оказывает крайне неблагоприятной действия не только на твердые ткани зубов, но и здоровье человека в целом [19]. Все это свиде- 
тельствует о том, что назрела необходимость осветить основные исследования отечественных и зарубежных ученых, в которых изложено современное состояние вопроса о гигиеническом значении фтора применительно, не только к гигиенической науке и санитарной практике, но и к социальной и медицинской значимости этого вопроса.

Известно, что фториды имеют безусловное физиологическое значение для организма человека и его здоровья, в том числе стоматологического. Они придает своим соединениям особую стабильность и устойчивость. Для нормального развития зубов необходимо определенное равновесие в зубной лимфе между ионами фтора и магния. Если равновесие нарушено в сторону увеличения магния и уменьшения фтора, то фосфатаза, влияя на дентин и эмаль, способствует развитию кариеса. Фториды также способствует связыванию фосфорнокислого кальция, являясь биокатализатором. Кроме того, фториды ингибируют активность ферментов, кофакторами которых являются ионы марганца, кальция, железа и, особенно, магния, образуя с этими элементами фторметаллические соединения. При этом высокие концентрации фторидов оказывают тормозящее влияние на тканевое дыхание головного мозга и печени, а количества фторидов в питьевой воде 1,0-1,5 мг/л оказывает на тканевое дыхание стимулирующий эффект [24]. Также известно тормозящее действие фторидов на иммунобиологическую реактивность организма, в частности агглютинирующую активность сыворотки крови [24, 30].

Сегодня установлена среднесуточная физиологическая потребность во фторидах для взрослого человека, которая составляет 2-3 мг [2]. Считается, что 70\% ее человек получает с питьевой водой и $30 \%$ - с пищей [4]. В то же время для фторидов характерен малый диапазон между биологически полезной (от 0,7 до $1,5 \mathrm{mr} / л)$ и токсической дозами [5]. Избыточное или недостаточное содержание фторидов в питьевой воде по ее внешнему виду и органолептическим показателям (по запаху, привкусу, цвету) не обнаруживается [5].

Следует отметить, что из-за различной растворимости соединений фтора его особенно много содержат термальные минеральные воды [3], вулканические газы, которые особенно богаты фтористым водородом [3]. Метеорные и поверхностные воды не богаты фторидами, а колодезная и артезианская воды часто богаты фтором, в отличие от атмосферных осадков, где фтора мало, всего около 0,05 мг/л [5]. Также необходимо добавить, что все большее влияние на кругооборот фтора оказывает производственная деятельность человека, особенно по переработке апатитов и фосфоритов [3, 4]. В настоящее время все минеральные элементы разделены на 3 группы по их отношению к кариесу, где фтор является элементом с выраженным противокариозным действием [32]. При этом участие фтора в биологических процессах зависит от климато-географических условий. Приняты расчетные концентрации фторидов в питьевой воде при различных температурах воздуха: при средней максимальной температуре $10-14^{\circ} \mathrm{C}$ расчетная концентрация фторидов в питьевой воде должна быть 1,2 мг/л, а при средней максимальной температуре $28-32^{\circ} \mathrm{C}$ расчетная концентрация фторидов в питьевой воде должна быть - 0,7 мг/л [23]. Однако, несмотря на знание физиологической роль фторидов, эти знания в полном объеме не используются в здравоохранении, в том числе и за рубежом [8, 20, 36, 38].

Несмотря на то что нет общепринятого согласия на механизм действия фтора, нет сомнений в отношении его противокариозного действия [7, 34]. Наиболее интенсивное включение фторидов в состав твердых тканей зубов, происходит во время их формирования и минерализации. По окончании роста и минерализации зубов эмаль и дентин зубов становятся менее проницаемыми для ионов фтора, но необходимость в них не исчезает [6, 28, 31, 37].

Ранее нами на основании стоматологического обследования 982 подростков (464 мужчины и 518 женщин) в возрасте 14-15 лет, постоянно проживающих в Москве, Санкт-Петербурге, Курске и их пригородах, с учетом места их проживания (мегаполис, районный центр, сельская местность) изучены распространенность и интенсивность течения кариеса зубов, а также степень активности течения кариеса и уровень индивидуальной гигиены полости рта у подростков мегаполиса и пригородов в современной России и показано, что у подростков, проживающих в мегаполисе и его пригородах, в том числе сельской местности, отмечается высокая распространенность течения кариеса зубов, которая составляет 91,6-97,6\%, а также большее число подростков с декомпенсированным течением кариозного процесса при сниженном уровне индивидуальной гигиены полости рта

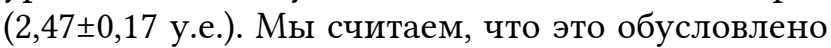
малой информированностью подростков и их родителей по вопросам индивидуального ухода за полостью рта, особенно в сельской местности, а также меньшей доступностью стоматологической помощи на селе в связи с удаленностью стоматологических лечебно-профилактических учреждений от мест проживания подростков. Согласно нашим данным показатель КПУ составил у жителей мегаполиса, районного центра и 
сельской местности соответственно 4,35 $\pm 0,21$;

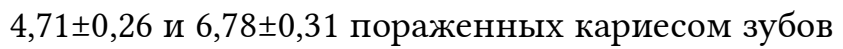
на одного подростка. При этом половых различий в интенсивности течения кариозного процесса у подростков мегаполиса, его районных центров и подростков, проживающих в сельской местности, нами установлено не было. Это подтверждает слова специалистов, свидетельствующих, что данный карие зубов, как социально значимый процесс, имеет характер «почти эпидемического распространения» [16]. Такая высокая пораженность зубов подростков приводит к высокой нуждаемости их в лечении кариеса и его осложнений, особенно у лиц призывного возраста, а также у военнослужащих срочной службы [9, 17]. Причем подчеркивается, что пораженность кариесом зубов рядового состава Российской армии и флота в XXI веке не имеет тенденции к снижению $[9,11]$.

Впервые фторирование централизованно подаваемой питьевой воды было осуществлено в Соединенных Штатах Америки (США) в 1945 г., а через 25 лет Всемирная организация здравоохранения (ВО3) рекомендовала всем странам повсеместно внедрять фторирование, призывая всех членов ВОЗ предусматривать фторирование воды в национальных программах здоровья [18]. Наиболее успешно эти предложения реализовывались в США, где уже в 90-х годах XX столетия централизованное фторирование было организовано в 42 крупных городах [27]. В результате более $72 \%$ населения США стали получать фторированную питьевую воду [33].

Наши исследования показали, что в настоящее время в организации фторирования питьевой воды, подаваемой населению централизованно, существует неблагоприятная тенденция. Например, в Ленинградской области в г. Зеленогорске питьевая вода забирается из реки Кан, где содержание фтора 0,008 мг/л, а также из подземных вод, где этот показатель доходит до 0,35 мг/л, что значительно лучше, но при смешивании этих вод на водоканале питьевая вода «на выходе» содержит фторидов до 0,012 мг/л.

Если в 80-х годах XX века фторирование воды осуществлялось более чем в 60 городах СССР, то в начале XXI века технология внедряется преимущественно в небольших населенных пунктах, например, в г. Гвардейске Калининградской области [26]. В мегаполисах (Москва, Санкт-Петербург) руководство водной отрасли (предприятий «Водоканал») считают фторирование воды нецелесообразным, так как на питьевые нужды идет очень незначительная часть водопроводной воды, менее $10 \%$ [14]. При этом в России редко можно увидеть в магазинах молоко и соль, содержащие фториды [10]. Про- граммы профилактики кариеса зубов с использованием фторидов разработаны, но применяются редко, причем от случая к случаю в отдельных дошкольных или школьных учреждениях, и то, как правило, при проведении диссертационных исследований [12]. В то же время в Соединенных Штатах Америки усилия, направленные на рациональное использование фторидов и улучшение индивидуальной гигиены полости рта, привели к значительному снижению кариеса зубов - до 65\%, где около $30 \%$ детей вырастают, практически не имея кариозных поражений зубов вообще, а большая часть очень незначительное количество [35]. Так, фторирование питьевой воды приводит к снижению кариеса на 50-60\%; фторирование питьевой воды в школах - на 40\%; использование внутриротовых системных фтористых добавок - на 50-65\%; использование фторидов в составе зубных порошков и паст - на 20-30\%; профессионально применяемые аппликации фторидов на 30-40\%; самостоятельные аппликации фтора, выполняемые пациентами в домашних условиях, - на 20-50\% [35]. Из-за недостатка фторидов в питьевой воде большая ставка делалась на чай, как на их источник [11]. Доказано, что байховые и кирпичные сорта чая реально являются источниками фторидов. Однако нет исследований, показывающих зависимость встречаемости и интенсивности кариеса зубов от выпитых кружек чая, особенно с учетом возраста.

Сегодня доказано, что фториды могут быть важным фактором в возникновении заболеваний человека (острые и хронические отравления фтором, хронический профессиональный флюороз, эндемический флюороз) [3], доказана их незаменимая роль в снижении заболеваемости кариесом зубов, особенно у детей и подростков $[2,25]$.

В настоящее время острые и хронические отравления фторидами практически не встречаются, а хронический флюороз выявляется у населения окрестностей заводов, в выбросах которых содержатся фториды [3]. Соблюдение технологии производства и правил техники безопасности на предприятиях на территории суперфосфатных и алюминиевых заводов исключает или резко снижает возможность попадания в верхние дыхательные пути и пищеварительный тракт фторсодержащей пыли [3]. Однако загрязнение воздушной среды таких заводов может приводить к тому, что в организм работающих на предприятии поступает подчас больше фторидов, чем с водой в эндемичных по флюорозу населенных пунктах, а следовательно, приводить к явлениям хронического флюороза, характеризующегося специфическими измене- 
ниями в костях и связочном аппарате, а не только зубах $[3,18]$.

В настоящее время на основании анализа результатов исследований сделаны выводы, что у лиц, проживающих в районах с оптимальной (1 мг/л) и умеренно повышенной $(2 \mathrm{мг/л)} \mathrm{кон-}$ центрацией фторидов в питьевой воде, не обнаруживаются существенные и стабильные отклонения в росте и развитии скелета. Концентрация фторидов в воде, приводящая к выраженному остеосклерозу, как правило, находится в пределах 5-13 мг/л при условии проживания в эндемическом районе не менее 10-15 лет [18]. Поэтому крайне важно использовать фториды для профилактики кариеса зубов.

В нашей стране до сих пор существует дефицит информации об экономической эффективности профилактических мероприятий фторидпрофилактики кариеса зубов. Однако в США еще в 70-80-е годы XX века были выполнены расчеты, показавшие, что выгода от фторирования питьевой воды в расчете на 1 человека в год составляет 1-2 доллара, а в крупных городах 10-20 центов. Учитывая расходы, связанные с лечением одного пораженного кариесом зуба, экономический эффект по соотношению расходов на фторирование и затрат на лечение достигал 1:100. В крупных городах, где стоимость фторирования меньше (10-20 центов на 1 чел. в год), этот показатель был на порядок выше [5].

Сегодня в России имеются достоверные результаты клинической оценки кариеспрофилактической эффективности фторсодержащих препаратов при различных методах и частоте их использования. Доказана экономическая эффективность профилактики кариеса препаратами, содержащими фториды: фтор-лак, витафтор, фторсодержащие таблетки [2, 6, 18, 39].

Особый прикладной интерес представляют предварительные расчеты, выполненные в системе Министерства обороны (МО) РФ в 2012 г., которые показали, что в РФ на лечение одного случая кариеса зубов за счет средств обязательного медицинского страхования (OMC) необходимо в среднем 500-600 руб. [21]. В условиях выраженности заболевания интенсивность кариеса в 2000-2010 гг. составила 7,7 зуба, а на лечение кариеса зуба у одного человека необходимо около 4,2 тыс. рублей [21]. В расчете на 250000 молодых людей, призываемых в течение года на военную службу, на эти цели должно быть предусмотрено около 1 млрд руб. В федеральной целевой программе «Чистая вода» на 2011 - 2017 гг.. для обеспечения населения «доброкачественной» питьевой водой планировалось осуществить финансирование в объеме 331,8 млрд руб. При расчете на одного жителя страны ежегодные затраты составили бы около
300 руб. Данная сумма предполагала затраты на улучшение качества воды в целом, то есть по всем показателям, исключая фторирование. В результате соотношение суммарных профилактических мер с затратами на лечение кариеса зубов составило бы 1:14 [21].

Поэтому в системе МО РФ затраты на фторидпрофилактику целесообразно рассматривать на примере использования индивидуальных средств ухода за полостью рта, содержащих фториды: зубные пасты и ополаскиватели для рта. Так, 30-граммовой тубы зубной пасты и 350 мл емкости ополаскивателя для полости рта, содержащих фториды, достаточно для использования одним человеком в течение месяца. Расходы на одного человека в год, исходя из применения 1 г зубной пасты и 20 мл ополаскивателя для рта в день, составят в среднем 2500 руб. в год, что также с экономической точки зрения можно оценить как один из достаточно эффективных способов решения проблемы.

Говоря об экономической целесообразности фторирования питьевой воды, необходимо рассмотреть вопрос о наличии фтораторных установок в крупных жилых комплексах мегаполисов, где в каждой квартире будет три крана воды: горячая, холодная и холодная питьевая. Причем, питьевая вода может быть фторированой. При этом себестоимость такой воды, прошедшей через фильтр и фтораторную установку, составил 10 - 15 копеек за литр, в отличие от питьевой воды, прошедшей только через фильтры, стоимость которой на сегодняшний день составляет 4 - 5 копеек за литр. Окупаемость необходимой техники и ее обслуживания, с учетом персонала, составит не более 5 - 7 лет.

Фторидсодержащие средства для ухода за полостью рта используются более полувека и в настоящее время признаны самым массовым средством профилактики кариеса зубов у детей и взрослых как в России, так и за рубежом [16, $18,27]$. Наиболее часто среди фторидов в средствах для ухода за полостью рта используются фторид олова, монофторфосфат натрия, фторид натрия, аминофториды, фторид алюминия как компоненты, входящие в состав зубных паст или ополаскивателей для рта $[13,18]$.

Резюмируя вышеизложенное, следует заключить, что в подавляющем большинстве населенных пунктов Российской Федерации содержание фторидов в питьевой воде очень низкое - менее 0,3 мг/л, в большинстве пищевых продуктов фториды содержатся в десятых долях миллиграмма на 1 кг массы и практически не осуществляется фторирование молока и соли. Централизованно профилактика кариеса зубов у детей и школьников в стране не осуществляется, прием таблеток фторида натрия, покрытие зу- 
бов фтор-лаком, аппликации фтор-гелем, а также полоскания и аппликации фторсодержащими растворами осуществляются либо индивидуально, либо в ограниченных коллективах детей, подростков и молодых людей, обычно при проведении научно-исследовательских работ. Поэтому для совершенствования общеоздоровительных и профилактических стоматологических лечебно-профилактических мероприятий в реальных условиях повседневной жизни целесообразно врачам разных специальностей:

- знать концентрацию фторидов в питьевой воде и в районах с низким и оптимальным их содержанием использовать местные фторсодержащие средства;

- рекомендовать фториды к ежедневному применению в малых концентрациях, например, детям с 2-летнего возраста осуществлять чистку зубов дважды в день фторсодержащей зубной пастой продолжительностью не менее 3 минут; детям до 6 лет при однократной чистке зубов использовать не более горошины зубной пасты, которая обычно будет содержать 500 ppm фторидов;

- $\quad$ зубные пасты с концентрацией фторидов от 500 до 5000 ppm назначать в зависимости от уровня риска развития кариеса зубов;

- ополаскиватели с концентрацией фторидов 0,025-0,05\% рекомендовать использовать детям с 6 лет и взрослым дважды в день после чистки зубов в течение 1 минуты;

- пациентам с высоким риском развития кариеса периодически (от 2 до 6 раз в год) осуществлять аппликации средствами для профессионального применения с высокой концентрацией фторидов;

- для пролонгирования эффекта местных фторсодержащих средств рекомендовать пациентам воздерживаться от приема пищи и напитков в течение часа после их применения.

В заключение также следует сказать, что рекламным акциям, направленным на более широкое применение населением России средств индивидуальной гигиены полости рта, содержащих фториды, в настоящее время характерна недостаточная убедительность и последовательность. В связи с этим существуют проблемы в готовности и понимании различными категориями населения важности ежедневного применения средств ухода за полостью рта, содержащих фториды. В связи с этим обстоятельством в организованных и неорганизованных коллективах фторсодержащие зубные пасты и ополаскиватели для рта применяются эпизодически. Это ситуация в стране требует немедленной коррекции.
Таким образом, проблема сохранения соматического и стоматологического здоровья у населения России, в том числе профилактики кариеса зуба, должна решаться в контексте климато-географических, экологических, медицинских и социальных аспектов, при этом фторидам должно отводиться важное место.

\section{КОНФЛИКТ ИНТЕРЕСОВ}

Автор декларирует отсутствие явных и потенциальных конфликтов интересов, связанных с публикацией настоящей статьи.

\section{ИСТОЧНИКИ ФИНАНСИРОВАНИЯ}

Автор заявляет об отсутствии финансирования.

\section{ЛИТЕРАTУРA/REFERENCES}

1. Боровский Е.В. Кариес зуба. Москва: ММСИ, 1972. 30 c. [Borovskiy E.V. Caries of tooth. Moscow: MMSI, 1972. 30 p. (in Russ.)]

2. Виноградова Т.Ф. Педиатру о стоматологических заболеваниях у детей. Ленинград: Медицина, 1982. 160 c. [Vinogradova T.F. For pediatrician about dental diseases in children. Leningrad: Meditsina, 1982. 160 p. (in Russ.)]

3. Габович Р.Д. Фтор и его гигиеническое значение. Москва: Медгиз, 1957. 252 с. [Gabovich R.D. Fluorine and its hygienic value. Moscow: Medgiz, 1957. 252 p. (in Russ.)]

4. Габович Р.Д., Минх А.А. Гигиенические проблемы фторирования питьевой воды. Москва: Медицина, 1979. 179 c. [Gabovich R.D., Minkh A.A. Hygienic problems of fluoridation of drinking water. Moscow: Meditsina, 1979. 179 p. (in Russ.)]

5. Габович Р.Д. Фторирование воды. В: Большая медицинская энциклопедия. Под ред. Б.В. Петровского. Москва: Советская энциклопедия, 1985. Том 26. C. 560. [Gabovich R.D. Fluoridation of water. In: Great medical encyclopedia. Petrovkiy B.V., editor. Moscow: Sovetskaya entsiklopediya, 1985. Vol. 26. P. 560. (in Russ.)]

6. Жидких В.Д. Результаты местной профилактики кариеса зубов у школьников. Стоматология. 1984;63(6):9-10 [Zhidkikh V.D. Results of local prevention of dental caries in schoolchildren. Stomatologiya. 1984;63(6):9-10 (in Russ.)]

7. Иорданишвили А.К., Ковалевский А.М. Стоматологические заболевания у подростков. В: Подростковая медичина: руководство для врачей. Под ред. Л.И. Левиной, А.М. Куликова. СанктПетербург: Питер, 2004. С. 462-475. [Iordanishvili A.K., Kovalevskiy A.M. Dental diseases in adolescents. In: Adolescent medicine: a guide for physicians. Levina L.I., Kulikov A.M., editors. Saint-Petersburg: Piter, 2004. P. 462-475 (in Russ.)]

8. Иорданишвили А.К. Клиническая ортопедическая стоматология. Москва: МедПресс, 2008. 208 с. [Иорданишвили А.К. Clinical orthopaedic dentistry. Moscow: MedPress, 2008. 208 p. (in Russ.)]

9. Иорданишвили А.К., Солдаткина А.С. Стоматологические заболевания у лиц призывного воз- 
раста. Вестник Российской Военно-медицинской академии. 2015;4(52):106-110 [Iordanishvili A.K., Soldatkina A.S., Serikov A.A. Dental diseases in people of recruit age. Vestnik Rossiyskoy Voyennomeditsinskoy akademii. 2015;4(52):106-110 (in Russ.)]

10. Иорданишвили А.К., Солдаткина А.С. Заболевания органов и тканей полости рта у лиц молодого возраста. Институт стоматологии. 2015;3(68):38-40. [Iordanishvili A.K., Soldatkina A.S. Diseases of mouth organs and tissues in young person. Institut stomatologii. 2015;3(68):38-40 (in Russ.)]

11. Иорданишвили А.К. Возрастные изменения жевательно-речевого аппарата. Санкт-Петербург: Издательство «Человек», 2015. 140 с. [Iordanishvili A.K. Age-related changes in the masticatory-speech apparatus. St. Petersburg: Publisher "Chelovek", 2015. 140 p. (in Russ.)]

12. Иорданишвили А.К., Пихур О.Л. Кристаллохимические аспекты в этиопатогенезе повышенной чувствительности зубов. Экология и развитие общества. 2017;4(23): 39-47 [Iordanishvili A.K., Pikhur O.L. Crystal chemical aspects in etiopathogenesis of hypersensitivity of teeth. Ekologiya $i$ razvitiye obshchestva. 2017;4(23): 39-47 (in Russ.)]

13. Иорданишвили А.К., Музыкин М.И., Васильев С.В. Фторид олова в профилактике и лечении повышенной чувствительности зубов. Экология $u$ развитие общества. 2018;2(25):42-45 [Iordanishvili A.K., Muzykin M.I., Vasil'yev S.V. Tin fluoride in the prevention and treatment of hypersensitivity of teeth. Ekologiya i razvitiye obshchestva. 2018;2(25):4245 (in Russ.)]

14. Кармазинов Ф.В. Водоснабжение СанктПетербурга. Санкт-Петербург: Новый журнал, 2003. 687 c. [Karmazinov F.V. Water supply of SaintPetersburg. Saint-Petersburg: Novyy zhurnal, 2003. 687 p. (in Russ.)]

15. Кодола Н.А., Коваленко А.И. Кариес зуба и содержание фтора в питьевой воде. Стоматология. 1977;56(3): 65-69 [Kodola N.A., Kovalenko A.I. Tooth decay and fluoride content in drinking water. Stomatologiya. 1977;56(3):65-69 (in Russ.)]

16. Кузьмина Э.М., Смирнова Т.А. Фториды в клинической стоматологии. Москва: ММСИ, 2001. 32 с. [Kuz'mina E.M., Smirnova T.A. Fluorides in clinical dentistry. Moscow: MMSI, 2001. 32 p. (in Russ.)]

17. Кузьмина Э.М., Янушевич О.О. Профилактическая стоматология. Москва: Практическая медицина, 2016. 543 с. [Kuz'mina E.M., Yanushevich O.O. Preventive dentistry. Moscow: Prakticheskaya meditsina, 2016. 543 p. (in Russ.)]

18. Кузьмина Э.М., Кузьмина И.Н., Лапатина А.В. Фториды в стоматологической практике: механизм действия, эффективность и безопасность применения. Москва: МГМСУ, 2018. 40 с. [Kuz'mina E.M., Kuz'mina I.N., Lapatina A.V. Fluorides in dental practice: mechanism of action, efficacy and safety of use. Moscow: MSMSU, 2018. 40 p. (in Russ.)]

19. Леонтьев В.К. Вопросы профилактики и лечения кариеса зубов и проблема реминерализации. Стоматология. 1977;56(2):89-92 [Leont'yev V.K. Issues of prevention and treatment of dental caries and the problem of remineralization. Stomatologiya. 1977;56(2):89-92 (in Russ.)]

20. Лопатин С.А., Мазуров В.И. Об участии санитарно-эпидемиологических учреждений Министерства обороны РФ в динамическом наблюдении за здоровьем военнослужащих. Военно-медицинский журнал. 1993;314(3):41-44 [Lopatin S.A., Mazurov V.I. About participation of sanitary and epidemiologic establishments of the Ministry of defence of the Russian Federation in dynamic supervision of health of the military personnel. Voyennomeditsinskiy zhurnal. 1993;314(3):41-44 (in Russ.)]

21. Малых А.Б., Гребнев Г.А., Буценко С.А., Пастухлов А.Г. Оказание зубопротезной помощи пенсионерам Министерства обороны в медицинских организациях государственной и муниципальной систем здравоохранения. Военно-медицинский журнал. 2012;333(4):4-13 [Malykh A.B., Grebnev G.A., Butsenko S.A., Pastukhlov A.G. Provision of dental prosthesis assistance to pensioners of the Ministry of defense in medical organizations of the state and municipal health systems. Voyennomeditsinskiy zhurnal. 2012;333(4):4-13 (in Russ.)]

22. Онищенко Г.Г., Рахманин Ю.А., Кармазинов Ф.В. Бенчмаркинг качества питьевой воды. СанктПетербург: Новый журнал, 2010. 432 с. [Onishchenko G.G., Rakhmanin Yu.A., Karmazinov F.V. Benchmarking of drinking water quality. SaintPetersburg: Novyy zhurnal, 2010. 432 p. (in Russ.)]

23. Пахомов Г.Н. Первичная профилактика в стоматологии. Москва: Медицина, 1982. 240 с. [Pakhomov G.N. Primary prevention in dentistry. Moscow: Meditsina, 1982. 240 p. (in Russ.)]

24. Пихур О.Л. Возрастные изменения состава и строения твердых тканей зуба. Санкт-Петербург: Нордмедиздат, 2015. 154 c. [Pikhur O.L. Age-related changes in the composition and structure of hard tooth tissues. Saint-Petersburg: Nordmedizdat, 2015. 154 p. (in Russ.)]

25. Сунцов В.Г., Леонтьев В.К., Дистель В.А., Вагнер В.Д. Стоматологическая профилактика у детей. Москва: Медицинкая книга; Нижний Новгород: НГМА, 2001. 344 с. [Suntsov V.G., Leont'yev V.K., Distel' V.A., Vagner V.D. Dental prevention in children. Moscow: Meditsinskaya kniga; Nizhny Novgorod: NSMA, 2001. 344 p. (in Russ.)]

26. Телевяк Н.Р. В г. Гвардейске Калининградской области введена в строй станция обезжелезивания воды. Вода magazine. 2012;6(58):4-5. [Televyak N.R. In the town of Gvardeysk, Kaliningrad region put into operation the station of deferrization of water. Voda magazine. 2012;6(58):4-5 (in Russ.)]

27. Addy M. Dentine hypersensitivity: New perspectives on an old problem. Int. Dent. f. 2002;52:367-375. DOI: 10.1002/j.1875-595X.2002.tb00936.x

28. Do L.G., Spencer A.J. Risk-benefit balance in the use of fluoride among young children. F. Dental Res. 2007;86(8):723-728.

DOI: $10.1177 / 154405910708600807$.

29. Elliott J.C. Calcium Phosphate Biominerals. Reviews in Mineralogy and Geochemistry. 2002;48:427-452. DOI: $10.2138 / \mathrm{rmg} .2002 .48 .11$ 
30. He T., barker M.L., Goyal C.R., Biesbrock A.R. Antigingivitis effects of a novel $0,454 \%$ stabilized stannous fluoride dentifrice relative to a positive control. Amer. F. Dent. 2012;25:136-140.

31. Marinho V.C. Evidence-based effectiveness of topical fluorides. $A d v$. Dent. Res. 2008;20(1):3-7. DOI: 10.1177/154407370802000102

32. Navia J.M. Prevention of dental caries with agents which increase tooth resistance to dental caries. Int. Dent. F. 1972;22:427-440.

33. Palmer C.A., Gilbert J.A. Position of the Academy of Nutrition and Dietetics: the impact of fluoride on health. I Acad Nutr Diet. 2012;112(9): 1443-1453. DOI: $10.1016 /$ j.jand.2012.07.012.

34. Siqueira J.F., Rocas I.N. Community as the unit of pathogenicity: an emerging concept as to the microbial pathogenesis of apical periodontitis. Oral. Surg.,
Oral. Med., Oral. Pathol., Oral. Radiol.,Endod. 2009;107:870-878. DOI: 10.1016/j.tripleo.2009.01.044

35. Stephen K.W. Fluoride toothpastes, rinses and tablets. Adv. Dent. Res. 1994;8(2):185-189. DOI: $10.1177 / 08959374940080020901$

36. Tinanoff N. Progress regarding the use of stannous fluoride in clinical dentistry. F. Clin. Dent. 1995; 6:3740.

37. Walker M. The pathogenesis and treatment of endoperiolesions. Pathogenesis. 2001;2(3):91-95.

38. Yamazaki H., Margolis H.C. Enhanced enamel remineralization under acidic conditions in vitro. 7 . Dental Res. 2008;87(6):569-574.

DOI: $10.1177 / 154405910808700612$

39. Zehnder M., Gold S.I., Hasselgren G. Pathologic interaction in pulpal and periodontal tissues. F. Clin. Periodontol. 2002;29(8):663-671. DOI: 10.1034/j.1600051x.2002.290801.x

Поступила в редакцию 22.04.2019

Подписана в печать 20.06.2019

Для цитирования: Иорданишвили А.К. Фториды: их значение для здоровья человека в современных условиях и перспективы использования. Курский научно-практический вестник «Человек и его здоровье». 2019;(2):66-73. DOI: 10.21626/vestnik/2019$2 / 07$.

\title{
FLUORIDES: THEIR VALUE FOR HUMAN HEALTH IN MODERN CONDITIONS AND PROSPECTS FOR THEIR USE
}

\author{
() Iordanishvili A.K. \\ North-Western State Medical University named after I.I. Mechnikov \\ (NWSMU named after I.I. Mechnikov) \\ 41, Kirochnaya St., Saint Petersburg, 191015, Russian Federation \\ S.M. Kirov Military Medical Academy (VMedA) \\ 6, Ac. Lebedev St., Saint Petersburg, 194044, Russian Federation \\ International Academy of Ecology, Man and Nature Protection Sciences (IAEMNPS) \\ 74, Bolshoy Av., Saint Petersburg, 199106, Russian Federation
}

\begin{abstract}
The article highlights the current issues in modern conditions which are associated with the consumption of fluoride by the population of Russia, including individual oral care products. It is noted that fluorides have unconditional physiological significance for the human body, its health, including dental. The effectiveness of fluoride drugs and their effect on the reduction of dental caries is widely documented in foreign and domestic literature and thus it is an indisputable fact. Despite the fact that there is no generally accepted agreement on the mechanism of fluorine action, there is no doubt in its anticaries action. The most intensive inclusion of fluorides in the composition of the hard tissues of teeth occurs during their formation and mineralization. At the end of teeth growth and mineralization, the enamel and dentin become less permeable to fluoride ions. The optimal daily intake of fluoride should range between 0.05 and $0.07 \mathrm{mg} / \mathrm{kg}$ body weight. Total fluoride intake should not exceed $0.1 \mathrm{mg} / \mathrm{kg}$ of body weight per day in order to avoid the appearance of dental and bony fluorosis. Recommendations on the use of fluoride-containing oral care products are given. It was noted that the problem of preserving the somatic and dental health of the population of Russia, including the prevention of dental caries, should be addressed in the context of climate-geographical, environmental, medical and social aspects, in the solution of which fluorides should play a significant role.

Key words: fluorides, human health, hygienic value of fluorine, safety of fluoride, tin fluoride, sodium monofluorophosphate, sodium fluoride, aluminum fluoride.

Iordanishvili Andrey K. - DM, Professor of Department of Prosthetic Dentistry, NWSMU named after I.I. Mechnikov, Saint Petersburg; Professor of Department of Maxillofacial Surgery and Surgical Dentistry, VMedA, Saint Petersburg; Chief Scientific Secretary, IAEMNPS, Saint Petersburg. E-mail: $\underline{\text { mdgrey@bk.ru }}$
\end{abstract}


Курский научно-практический вестник "Человек и его здоровье". - 2019. - № 2.

\section{CONFLICT OF INTEREST}

The author declares the absence of obvious and potential conflicts of interest related to the publication of this article.

\section{SOURCE OF FINANCING}

The author states that there is no funding for the study.

Received 22.04.2019

Accepted 20.06.2019

For citation: Iordanishvili A.K. Fluorides: their value for human health in modern conditions and prospects for their use. Kursk Scientific and Practical Bulletin "Man and His Health". 2019;(2):66-73. DOI: 10.21626/vestnik/2019-2/07. 